\title{
A Stress Inoculation Program to Cope with Test fnxiety: Differential Efficacy as a Function of Worry or Emotionality
}

\author{
Programa de inoculación de estrés para hacer frente a la ansiedad ante los \\ exámenes: eficacia diferencial en función de la preocupación 0 emocionalidad \\ Programa de inoculação de stress para fazer frente à ansiedade ante os exames: \\ eficácia diferencial em função da preocupação ou emocionalidade.
}

\author{
Isabel Serrano Pintado, ${ }^{*}$ Juan Delgado Sánchez-Mateos, ${ }^{*}$ M. Camino Escolar-Llamazares ${ }^{* *}$ \\ "Salamanca University, Spain. ${ }^{* *}$ Burgos University, Spain.
}

Doi: dx.doi.org/10.12804/ap134.1.2016.01

\begin{abstract}
flbstract
Objective: This study experimentally investigated whether the effects of three different coping programs designed to reduce test anxiety were due to the predominant component of participants' anxiety. Design: The study involved 259 participants, high text anxiety university students, real clinical cases collected and studied during eight years. The experimental sample was finally composed of 94 selected participants with irrational test anxiety. The experimental factors were: Therapy (intra-subject factor, pre and post- intervention), Treatment (cognitive, physiological and cognitive-physiological), Worry (high-low) and Emotionality (high-low). Measures: Several anxiety questionnaires (TAS, TAI, ITA, CI, STAI) were used as indicators of anxiety. Results: Using confidence intervals, we found evidence of changes in the level of measured anxiety in varied degree in the
\end{abstract}

different Worry and Emotionality groups. Conclusion: The three different training programmes reduced test anxiety but did not lead to reductions on the same scale in pre-test anxiety in different groups of emotionality and worry. These results could be decisive in the phase of selection of the most suitable treatment for the patient along the therapeutic process.

Keywords: worry; emotionality; test anxiety; treatment; university students; state-trait anxiety.

\section{Resumen}

Objetivo: Este estudio investigó experimentalmente si los efectos de tres programas diferentes de afrontamiento, diseñados para reducir la ansiedad ante los exámenes, se deben al componente predominante de la ansiedad de los participantes. Diseño: El estudio incluyó 259 participantes, estudiantes universitarios con alta ansiedad

* Isabel Serrano Pintado, profesora del Departamento de Personalidad, Evaluación y Tratamiento Psicológico, Facultad de Psicología, Universidad de Salamanca, España; Juan Delgado Sánchez-Mateos, profesor del Departamento de Metodología de las Ciencias del Comportamiento, Facultad de Psicología, Universidad de Salamanca.

${ }_{* *}^{*}$ M. Camino Escolar Llamazares, profesora del Área de Personalidad, Evaluación y Tratamiento Psicológico, Facultad de Ciencias de la Salud, Universidad de Burgos, España.

Correspondence: M. Camino Escolar Llamazares, Facultad de Ciencias de la Salud, Universidad de Burgos, Paseo Comendadores s/n. Burgos, 09001, España. E-mail: cescolar@ubu.es

How to cite this article: Serrano, I., Delgado, J., \& Escolar-Llamazares, M. C. (2016). A stress inoculation program to cope with test anxiety: differential efficacy as a function of worry or emotionality. Avances en Psicología Latinoamericana, 34(1), 3-18. doi: dx.doi.org/10.12804/apl34.1.2016.01 
ante los exámenes, casos clínicos reales recogidos y estudiados durante ocho años. La muestra experimental quedó formada por 94 participantes seleccionados con ansiedad irracional ante los exámenes. Los factores experimentales fueron: terapia (factor intrasujeto, pre y postintervención), tratamiento (cognitivo, fisiológico y cognitivo-fisiológico), preocupación (alta-baja) y emocionalidad (alta-baja). Medidas: Se utilizaron varios cuestionarios de ansiedad (TAS, TAI, ITA, IC, STAI) como indicadores de ansiedad. Resultados: Utilizando intervalos de confianza, se encontró evidencia de cambios en la ansiedad, medida en un grado variado en los diferentes grupos de preocupación y emocionalidad. Conclusión: Los tres programas de entrenamiento reducen la ansiedad ante los exámenes; pero no se produce en la misma medida en los diferentes grupos de emocionalidad y de preocupación. Los resultados podrían ser decisivos en la fase de selección del tratamiento más adecuado para el paciente a lo largo del proceso terapéutico.

Palabras clave: preocupación; emocionalidad; ansiedad ante los exámenes; tratamiento; estudiantes universitarios; ansiedad estado-rasgo.

\section{Resumo}

Objetivo: Este estudo pesquisou experimentalmente se os efeitos de três programas diferentes de afrontamento, desenhados para reduzir a ansiedade ante os exames, devem-se ao componente predominante da ansiedade dos participantes. Desenho: O estudo incluiu 259 participantes, estudantes universitários com alta ansiedade ante os exames, casos clínicos reais recolhidos e estudados durante oito anos. A amostra experimental ficou formada por 94 participantes selecionados com ansiedade irracional ante os exames. Os fatores experimentais foram Terapia (fator intra-sujeito, pré e pós-intervenção), Tratamento (cognitivo, fisiológico e cognitivo-fisiológico), Preocupação (alta-baixa) e Emocionalidade (alta-baixa). Medidas: Vários questionários de ansiedade (TAS, TAI, ITA, IC, STAI) foram utilizados como indicadores de ansiedade. Resultados: utilizando intervalos de confiança, encontramos evi- dência de mudanças no nível de ansiedade medido em um grau variado nos diferentes grupos de Preocupação e Emocionalidade. Conclusão: os três programas de treinamento reduzem a ansiedade ante os exames, mas esta redução não se produz na mesma medida nos diferentes grupos de emocionalidade e preocupação. Estes resultados poderiam ser decisivos na fase de seleção do tratamento mais adequado para o paciente ao longo do processo terapêutico.

Palavras-chave: preocupação, emocionalidade, ansiedade ante os exames, tratamento, estudantes universitários, ansiedade estado-rasgo.

Many college students need to solve the problem that causes them test anxiety (Cunha \& Paiva, 2012; Escalona \& Miguel-Tobal, 1996; Lowe \& Ang, 2012; Miralles \& Hernández, 2012; Orejudo, Herero, Ramos, Turrado \& Nuño, 2007). The importance of the negative consequences that this type of anxiety has on students (Amutio \& Smith 2008; Bonaccio, Reeve \& Winford, 2012; Conley \& Lehman, 2012; Gutiérrez-Calvo, 1996; Miralles \& Sanz, 2011; Nemati \& Habibi, 2012; Polo, Hernández \& Pozo, 1996; Szafranski, Barrera \& Norton, 2012) makes it necessary to implement treatment programs to control this type of anxiety and develop effective therapeutic methods that are based on studies of their effectiveness (Zeidner, 2007).

Emotion-oriented behavioral interventions are mainly effective in the reduction of the emotional component of test anxiety. Cognitive interventions appear to be more successful than the behavioral interventions in the reduction of the responses of test anxiety, both in emotional and cognitive components. Despite of this fact, by themselves in isolation, these two types of intervention (behavioral and cognitive) do not seem to improve performance. Cognitive-behavioral combination seems to be the most effective intervention in the treatment of test anxiety (Allen, 1980; Ergene, 2003; Erwin-Grabner, Goodill, Hill \& Neida, 1999; Escolar \& Serrano, 2012; Hembree, 1988; Hernández, 
Pozo \& Polo, 1994; Paulman \& Kennelly, 1984; Serrano \& Delgado, 1991; Serrano, Escolar \& Delgado, 2002; Sharma, 2002; Spielberger, Gonzalez \& Fletcher, 1979; Vagg \& Spielberger, 1995).

On the other hand, different studies seem to support the effectiveness of study skills training combined (not implemented in isolation) with cognitive, behavioral or cognitive-behavioral therapy to improve performance and decrease test anxiety response (Ergene, 2003; Erwin-Grabner et al., 1999; Escolar \& Serrano, 2012; Furlan, Sanchez-Rosas, Sebastián-Piemontesi \& Illbele, 2009; Hernández et al., 1994; Miralles \& Hernández, 2012; Miralles \& Sanz, 2011; Sapp, 1999; Sharma, 2002; Spielberger et al., 1979; Vagg \& Spielberger, 1995).

While many intervention programs have been effective in reducing test anxiety, it is also true that the type of intervention most appropriate for a particular patient type is not yet firmly established. In this respect, Zeidner notes that:

Furthermore, despite earnest efforts by practitioners to individualize treatments to the particular needs and problems of test-anxious students, we still do not have clear evidence to indicate which of the various intervention approaches is most effective for particular types of test-anxious students or for treating different manifestations of test anxiety. (2007, p. 178)

Thus, Can, Debory and Eskin (2012) compared the efficacy of systematic desensitization (behavior therapy) and cognitive restructuring (cognitive therapy) in reducing high scores on test anxiety, guided by the hypothesis that cognitive restructuring would be superior to systematic desensitization in reducing the severity of cognitive symptoms of anxiety, while systematic desensitization would be superior to cognitive restructuring in reducing the severity of the physiological symptoms of anxiety. The results showed that both types of therapy were equally effective in reducing the cognitive and phy- siological components of test anxiety. Finger and Galassi (1977) obtained similar results. However, other studies have reported that cognitive therapy is more effective than behavioral therapy (Holroyd, 1976; Kaplan, McCordick \& Twitchell, 1979).

On these grounds it seems to be necessary to take into account the patient characteristics concerning the different components of test anxiety. In this way, therapy for students who have test anxiety will be optimized.

Our study, responding to this problem, compares the effects of two types of intervention, cognitive and relaxation training, taking into account the levels of worry and emotionality recorded with different instruments for assessing the test anxiety. To this purpose we used the strategy of dismantling a program that includes cognitive training and relaxation. In a previous study (Serrano, Delgado \& Escolar, 2010) we presented the results obtained for some of these instruments. Here we present the results obtained with other instruments and we deepen the analytical strategy previously used. We analyze, using different perspectives and methods, part of the general data from previously unpublished research (Escolar, 2007).

Specifically, the objectives of the study were:

1. To test whether different training programs reduce the level of test anxiety as measured on different scales or instruments.

2. If there is a reduction, to prove if it does it occur to the same extent with either of the programs used.

3. If there are differences, to test whether the type of therapeutic intervention has a different impact on the way they face test anxiety depending on the patients main affected variable: worry (cognitive level) and emotionality (physiological level). In accordance with Liebert and Morris (1967), we understand emotionality as the physiological-affective experience generated by autonomic arousal. 
4. From the methodological point of view, to reanalyze data more appropriately according to the sample finally obtained.

\section{Conceptualization of test anxiety}

In all our research we consider "test anxiety" as a construct based on two facets. The first of these is its nature. We agree with Spielberger and his colleagues (Spielberger, 1972a, 1972b, 1980; Spielberger, Anton \& Bedell, 1976; Spielberger et al., 1979; Spielberger, Gonzalez, Taylor, Algaze \& Anton, 1978; Spielberger \& Vagg, 1995) who state that it is an anxiety trait specific to certain situations. This implies that people with high test anxiety respond to the evaluative threat for most test situations with a greater increase in their state of anxiety than people with low levels (Serrano, Delgado, \& Escolar, 2010; Zeidner, 2007). Recently, other authors have shared this definition of test anxiety (Can, Dereboy \& Eskin, 2012; Cunha \& Paiva, 2012; Nemati \& Habibi, 2012; Piemontesi, Heredia, Furlan, Sanchéz-Rosas \& Martínez, 2012; Putwain \& Sysmes, 2012). The second aspect is the differentiation of types of students who may have test anxiety. Like Naveh-Benjamin, McKeachie and Lin (1987) and Naveh-Benjamin (1991) we differentiate between students without study skills and without self-control skills over their study behavior, and students who have these skills in their behavioral repertoire and put them into practice. In the first case, and alluding to the distinction by Wolpe (1958), we are talking about rational anxiety and in the second case about irrational anxiety.

The present study falls in the field of irrational test anxiety. These are, therefore, students who in test situations, although properly prepare, suffer debilitating fear which has as a consequence low academic performance or even avoidance behaviors (Serrano \& Delgado, 1990; Serrano et al., 2010; Serrano \& Escolar, 2011; Serrano et al., 2002; Serrano, Escolar \& Delgado 2011).

\section{Method}

\section{Participants}

From 1997 to 2004, 259 university students with test anxiety accessed the services offered by the Psychological Services Unit of the University of Salamanca. The age and sex sample composition, obviously, could not be foreseen. We selected those who did not exhibit other types of anxiety and whose study habits were adequate. The final sample was reduced to 94 cases for which complete records were available. Being actual clinical cases, how many would use the Psychological Care Unit each year could not be determined in advance. Therefore, the annual composition of the sample was irregular. After eight years data collection was terminated. The research was done with the knowledge and written consent of each of the participants.

\section{Measures}

To rule out students with other anxiety disorders or with "rational test anxiety" problems, according to our conceptualization of the construct, we used the State-Trait Anxiety Inventory (STAI E/R; Spielberger, Gorsuch \& Lushene, 1970) and the Inventario de Hábitos de Estudio (Study Habits Inventory) (IHE; Pozar, 1979) which assesses student work and study habits using four scales. The IHE, according to the split-half method, has a reliability index greater than .91 .

To evaluate "irrational test anxiety" in its physiological and cognitive components we used:

- The Test Anxiety Inventory (TAI; Spielberger, 1980) measures the physiological and cognitive manifestations of trait test anxiety. It has a Cronbach alpha coefficient reliability index of 92 .

- The Test Anxiety Scale (TAS; Sarason, 1978) measures the physiological and cognitive 
manifestations of test anxiety. The test-retest reliability index is .87 (Wagaman, Cornier \& Cornier, 1975).

- The Inventory of Test Anxiety (ITA; Osterhouse, 1969) measures the physiological and cognitive response to the test anxiety state. Osterhouse developed it specifically to measure the effects of treatments aimed at reducing test anxiety. Reliability obtained by the split-half method was 92 (McMillan \& Osterhouse, 1972; Osterhouse, 1972).

- The Cognitive Interference Questionnaire (CIQ; Sarason, 1984) measures the cognitive response to the test anxiety state. Specifically, it measures the frequency of aversive and task irrelevant thoughts.

- Record the Subjective Units of Anxiety (SUA) manifested by participants, using a scale with values that go from zero (completely relaxed) to 100 (extremely tense).

- Self-report by patients about their current state and performance.

In this article we will refer to the data obtained using the TAS inventories and the CIQ score. To see the data obtained from the TAI and ITA inventories see Serrano et al. (2010).

\section{Procedure}

The general procedure was carried out in the following stages:

1. Pretreatment evaluation of situational test anxiety. Students were assessed immediately after taking one of the most difficult exams, according to student, in the first quarter.

2. Application of the program. The intervention is based on the stress inoculation paradigm. Participants in the cognitive therapy group were trained in cognitive restructuring and thought stopping. Participants in the physiological treatment group were trained in relaxation. Participants in the combined treatment group were trained in relaxation and cognitive training.

The assignment of each person to a type of therapy was carried out using an inter-intra factorial design with two factors and six groups as shown in the diagram in the design section. Originally the patients were treated using conventional therapy (combined). Over time the cognitive and physiological components of the therapy (dismantling) were tested trying to balance the sample sizes. It is important to note that, since this was a therapeutic process and not a randomized experiment, equal sample sizes could not take precedence over achieving the therapeutic end:

1. Later, each group of participants, using the specific skills learned, faced, in imagination, the anxiety arousing situations of their respective anxiety hierarchies.

2. Then, all participants faced in vivo situations when they took their exams (final exams usually from June to July).

3. Post treatment evaluation. Participants were assessed immediately after completing one of the most difficult final exams, according to the student.

\section{Design}

The factors considered were:

Therapy. Pre-treatment and post-treatment intra-subject factor data were obtained.

Type of treatment. As noted above: (1) cognitive treatment, (2) physiological treatment, and (3) combined therapy: cognitive + physiological.

Worry. Was obtained by dividing the participants into two groups using the "k-means" partitioning procedure into two clusters according to the variability of the subject on the worry scales of the TAI, TAS and ITA inventories. Thus, (1) high worry and (2) low worry groups were defined. 
Emotionality. Was obtained by dividing the participants into two groups using the "k-means" partitioning procedure into two clusters according to the variability of the subject on the emotionality scales of the TAI, TAS and ITA inventories and the CIQ scale. Thus (1) high emotionality and (2) low emotionality groups were defined.

All this results in a mixed factorial design scheme with one intra-subjects variable (Therapy) and three inter-subjects variables (Treatment, Preoccupation, and Emotionality). Given its applied nature and the fact that study was conducted with diagnosed clinical cases that needed psychological therapy, it was not possible to predetermine how many participants would predominate a component of high or low emotionality or high or low worry. Thus, randomization or balancing cases on the factors was not possible. And the cell size of the design could not be equal, or even proportional, which posed difficulties in analyzing the results.

\section{Results}

Analysis of Variance was performed using the GLM Repeated Measures in SPSS. The objectives of the study were achieved by analyzing third-order interactions (Therapy $\times$ treatment $\times$ Preoccupation $\times$ Emotionality). Due to the small size of some of the cells, the study power was low and did not meet the usual criteria for statistical significance. But a single value (a single $F$ for third-order interaction) can be regarded as an "omnibus" test, not as a focused analytic procedure) (Rosenthal, Rosnow \& Rubin, 2000). A process that allows us to decompose the various integrated simple main effects in this interaction consists of the visual inspection (Cumming \& Finch, 2005) of the confidence intervals around the means of the 24 cells of the design.

Larger sample sizes would obtain statistical significance, but getting suitable sizes would mean having prolonged the study many more years. The composition of the sample has already been des- cribed and justified. Under these conditions, statistical tests with dichotomous decisions and power analysis are particularly poorly suited. Therefore, and for the reasons given above (focused analytic procedure) we chose analysis using confidence intervals.

We have chosen to analyze the differences between the scores before treating participants (pre-treatment) and the scores after treatment (post-treatment). Comparison of confidence intervals for correlated data, such as those coming from repeated measures as in this design, cannot be accurately done without taking into account the correlations. The correct choice, in this case, is to assess the confidence intervals of the differences between the pre- and post-treatment means, or gain scores (Cumming \& Finch, 2005). Loftus and Masson (1994) propose another method for estimating the confidence intervals in this type of design, but we consider the calculation of gain scores simplest and best adapted to the problem of eventual improved scores after treatment.

Means and standard errors were obtained with the SPSS GLM program with standard errors adjusted for design features using suitable weights (Federer \& King, 2007; Fox, 2008; Kirk, 1995) for the design features. With these values the confidence intervals were constructed using programmed routines in R (R Core Team, 2013) with the "gplots" package (R. Warnes. Version 2.11.0.1).

The data are analyzed and interpreted following the recommendations of Meehl (1997), Cumming (2009), Cumming and Maillardet (2006), and Cumming et al. (2007).

The criterion for statistical significance, in addition, can be replaced with advantage by:

1. The replicability of findings. In this case, replication in the same study with different variables, with consistent results among them. Replicability and consistency is decisive evidence (Beyth-Marom, Fidler \& Cumming, 2008; Cumming, 2010). 
2. The importance of the therapeutic effects, that is, changes from the point of view of therapeutic goals. Over the years, with these samples and others not related to this study, we have obtained consistent reductions in anxiety. As a concurrent criterion of therapeutic efficacy (importance) of which there is documentary evidence, we can add the qualitative evidence that the participants have communicated to us their subjective feelings of improvement. Let us add to these the attainment of the clinical goal: adequate coping in examination contexts without tension, as a fundamental criterion.

Next, we show the analysis of the variables described in the previous section. The rest of the results, as already noted, can be found in Serrano et al. (2010).

\section{Variable: Trait}

TAS-T inventory (total score) that assess the test anxiety trait for emotionality and worry variables together (see figure 1).

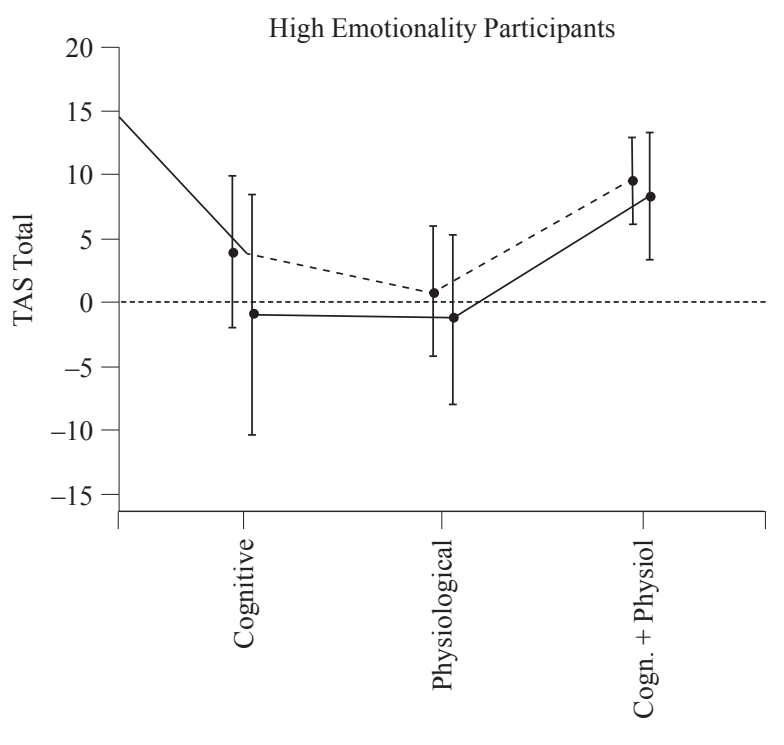

- High worry participants $\searrow$ _. Low worry participants
In the left panel of the figure, for participants of high emotionality, the differences between the before and after scores for each type of treatment are compatible with zero except for the combined treatment; these differences should be considered significantly different from zero. This is true for participants with high and low levels of worry.

In the right panel of Figure 1, for low emotionality subjects, the differences between the scores before and after each type of treatment are consistent with zero except for high-worry participants who improve with combined and physiological therapies (ranges that exclude the zero value). In cognitive therapy treatment groups there are intervals that include zero although very marginally, at the borders of the interval limit. These results considered concurrently with others that will be explained later are worthy of note.

TAS-W inventory (test anxiety trait, worry component). The results are similar to those encountered with TAS-T. In the graph on the left panel of figure 2 we see intervals that do not include the zero value in the combined treatment for high emotionality participants in the high and low worry groups.

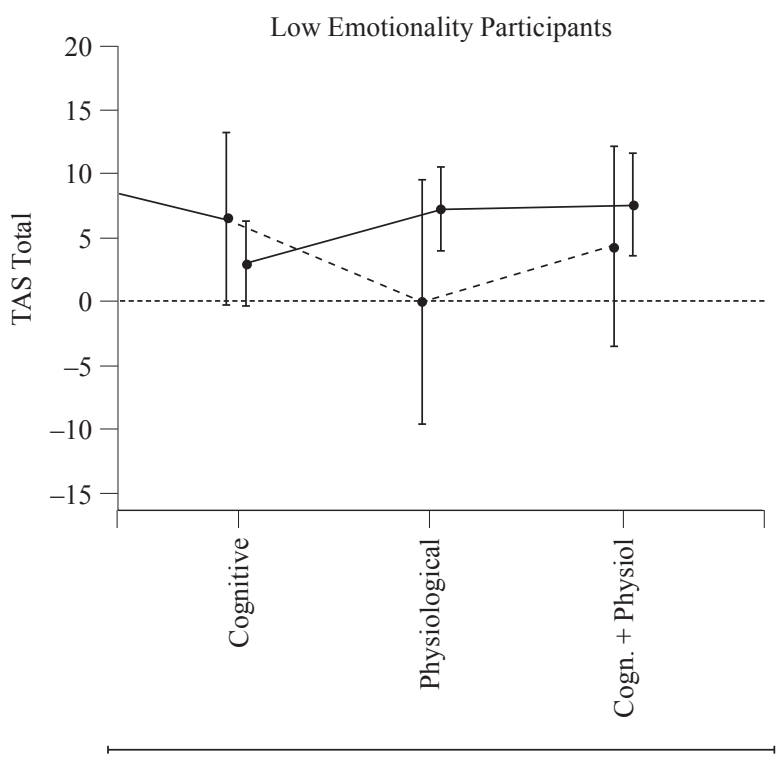

_ High worry participants ___ Low worry participants

Figure 1. Confidence intervals around TAS inventory total score means 
For participants with low emotionality (right panel of figure 2), in all treatments we find differences in the groups of people with high worry, although in a borderline or marginal form for cognitive therapy.

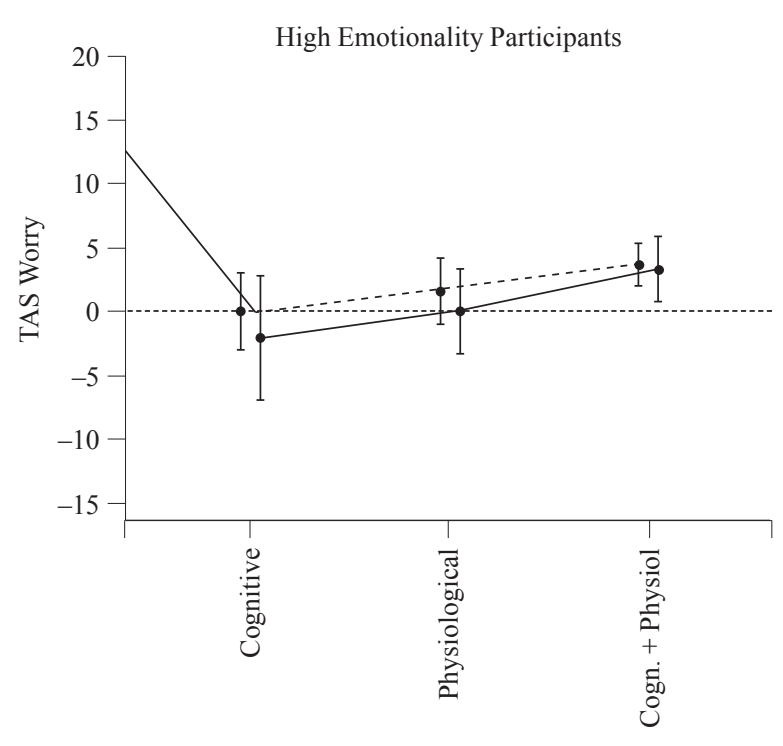

_ High worry participants $\searrow$ - Low worry participants
TAS-E inventory (test anxiety trait, emotionality component). In the left panel of figure 3 , high emotionality participants, we find results consistent with those previously discussed with TAS-T and TAS-W. In contrast, in the right panel of figure 3 ,

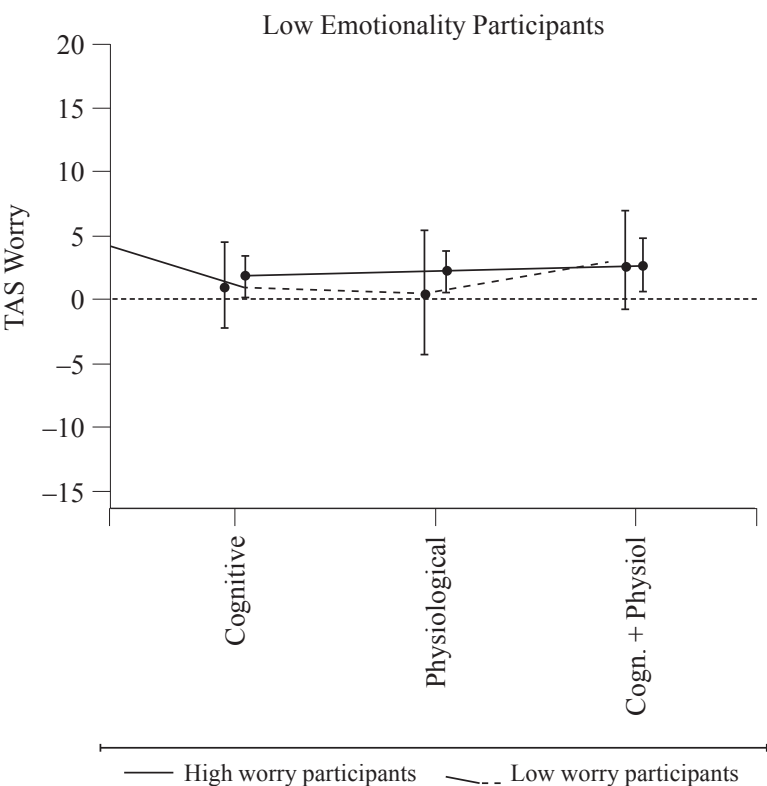

Figure 2. Confidence intervals around TAS inventory Worry Score means
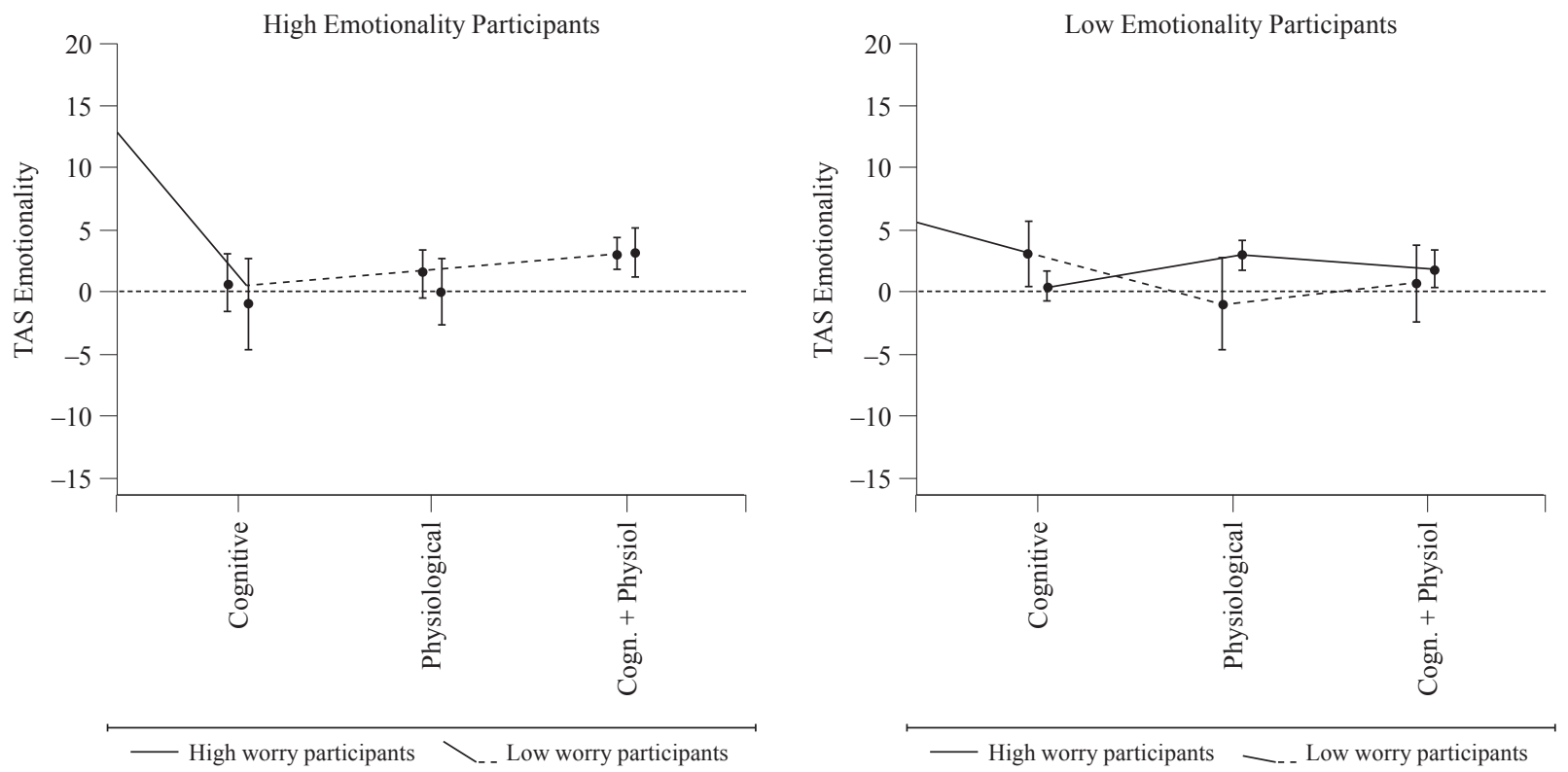

Figure 3. Confidence intervals around TAS inventory Emotionality Score means 
for participants with low emotionality, something new is seen: the pre-post-treatment differences for the low worry group are not compatible with the zero value for the cognitive treatment, albeit borderline. They are clearly different from zero in the high worry group with the physiological treatment. They are different from zero, although borderline, for the high worry combined treatment group.

\section{Variable: State}

CIQ-T inventory (test anxiety state, cognitive and preoccupation dimension). In the left panel of Figure 4, high emotionality participants, we found the following results: The pre-post-treatment differences do not include the zero value in the high worry combined therapy group. However, in the low worry group, these differences are significantly different from zero with the three therapies although cognitive therapy results are almost bordering on zero, and those of physiological therapy are the most distant from zero.

In the right panel, low emotionality participants, the results are similar but deserve a separate com-

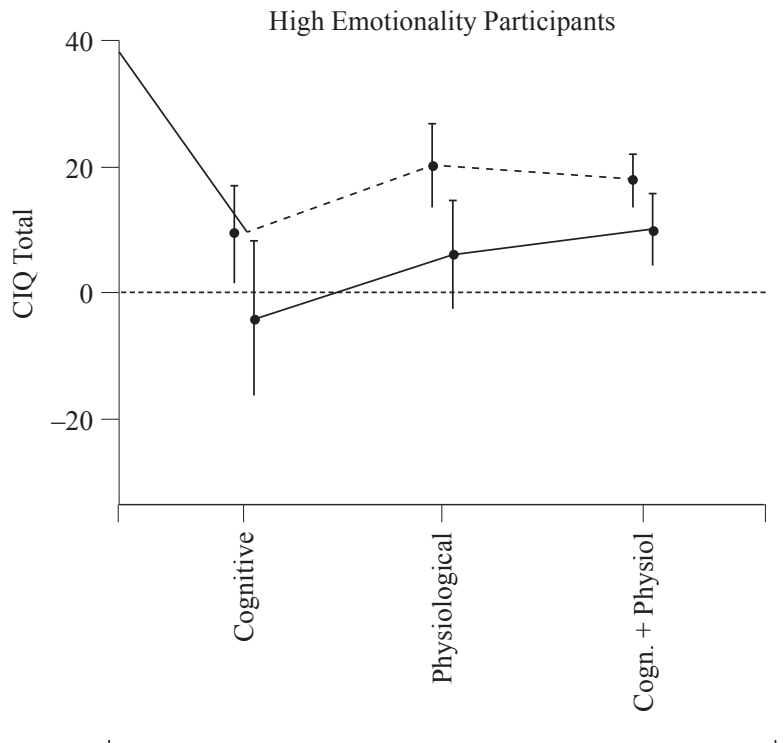

- High worry participants $\searrow_{-}$. Low worry participants ment. Considering only the means of the interval values, all are greater than zero. The lower variability of the high worry group leaves the confidence interval at the borderline for the high worry combined therapy treatment group. Regarding the low worry groups, once again physiological therapy treatment participants show the greatest pre-posttreatment differences from zero. In those treated with cognitive and combined therapies, incompatible differences are obtained with the zero value but less distant than this one.

\section{Discussion and conclusion}

\section{Trait anxiety}

Given these results and those reported in Serrano et al. (2010) for inventories assessing worry and emotionality test anxiety traits together, similar results are obtained with different tests and the importance of change is kept. In summary, we found that the combined treatment produces the main improvement in individuals who start out at high levels of worry and emotionality. The

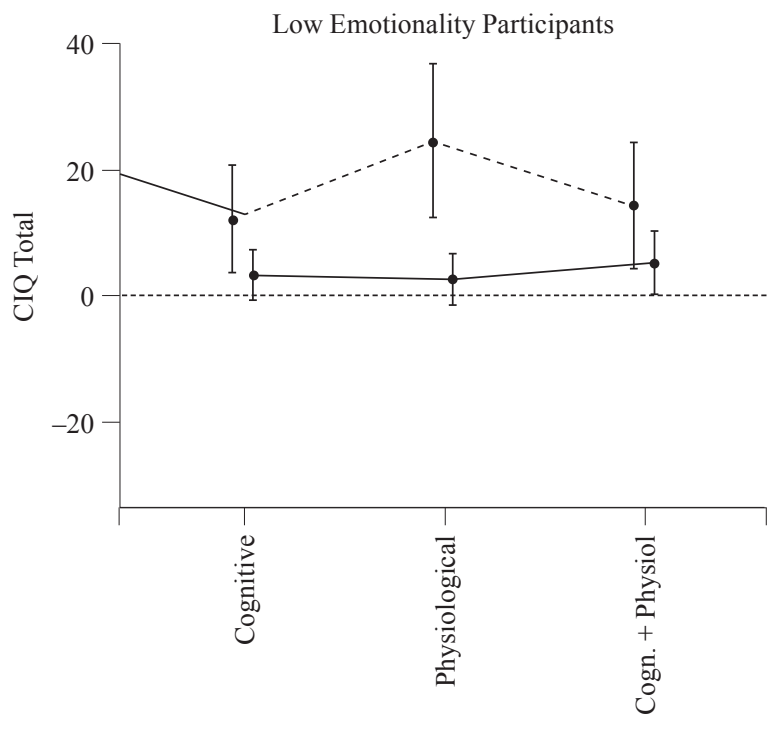

_ High worry participants __ _ Low worry participant

Figure 4. Confidence intervals around CIQ Inventory total score means 
same goes for individuals who have high levels of emotionality and low levels of worry. Individuals who initially have low levels of emotionality and high levels of worry improve with physiological and combined therapy but not with cognitive therapy. However, individuals who have low levels of emotionality and worry get slightly more benefit from cognitive therapy than with combined therapy. There is no benefit seen from the physiological treatment.

Analyzing the emotionality and worry dimensions separately, the results are similar. With combinations of high levels of emotionality with high or low levels of worry, combined therapy ensures greater level of improvement. In individuals with low levels of emotionality and high levels of worry the greatest benefit is obtained with physiological and combined therapies. However, individuals with low levels of worry and emotionality seem to benefit most from cognitive treatment, that being said with some caution since the confidence intervals in this group are very broad, probably due to small sample size.

\section{State anxiety}

The results, in accordance with Serrano et al. (2010), allow us to conclude for the worry component that in state anxiety before exams, the same interaction appears as in the trait anxiety results although with different nuances. Once again, combined treatment produces only significant improvement for participants with high levels of worry and emotionality. For individuals with low levels of emotionality and high levels of worry combined therapy would also be advisable. That is, whenever we go to treat individuals with high levels of preoccupation we should apply the combined treatment. On the other hand, participants with high levels of emotionality and low levels of preoccupation obtained greater improvement with physiological therapy and slightly less with the combined therapy and lower reduction with cognitive therapy.
Physiological treatment is also more efficient for individuals that start with low levels of emotionality and worry, although cognitive and combined treatments would also be effective although to a lesser extent. These results imply that physiological treatment would be recommended for individuals with high levels of emotionality and low levels of worry as well as for individuals with low levels of emotionality and worry.

Choosing physiological treatment for this type of individual would be supported by those who have shown that people exposed to stressful situations have difficulty executing complex mental operations which deal with stress (Gaudry \& Spielberger, 1971). And conversely, relaxation treatment (Hernández et al., 1994; Spielberger \& Vagg, 1995) applied during the assessment counteracts the activation state of the individual and reduces subjectively experienced anxiety as well as tension. That is, in these participants, physiological treatment possibly acts positively on the cognitive manifestation of anxiety.

It is true that some studies (Fletcher \& Spielberger, 1995; Gonzalez, 1995; Parker, Vagg \& Papsdorf, 1995), suggest that cognitively focused treatments have been consistently more successful than emotionally focused treatments in reducing test anxiety and their emotionality and worry components. But it is of great importance to note that none of these studies has considered the prior interindividual variability of these students that we have controlled for.

Therefore, we conclude, in general, that there are differences in efficacy in coping strategies in reducing test anxiety depending on the variable mainly affected. And specifically that:

1. The various training programs do reduce (significantly) the degree of test anxiety.

2. This reduction does not occur to the same extent with the three intervention programs.

3. Proved the existing differences between treatments, participants who present high levels in 
any dimension are benefited mainly by combined treatment.

4. However, which treatment should be chosen for individuals with low levels of emotionality and worry depends on if we are more interested in reducing anxiety trait levels or the anxiety state since in the first case we should opt for the cognitive treatment while in the second case we should opt for physiological treatment.

These findings are absolutely relevant and decisive, at the stage of choosing the ideal treatment for the patient throughout the treatment process. In addition, we respond to different authors who such as Martínez-Monteagudo, Inglés, Cano-Vindel and García-Fernández (2012) have concluded, in relation to general anxiety, that the different components of the anxiety response result in differential response profiles, raising the need to evaluate them to determine the precise adjustment of subsequent treatment depending on the response to treatment and the predominant anxiety component in the patient (cognitive, physiological or behavioral). This ultimately, according to these authors, leads to a reduction in the financial and time costs of interventions. In this line, Furlan et al. (2009) note that multidimensional test anxiety assessment would specify the areas in which the symptoms are more pronounced in each student, and adapt intervention strategies accordingly.

Moreover, the conclusions of this study are consistent with other authors such as Miralles and Hernández (2012), Miralles and Sanz (2011), Onwuegbuzie and Daley (1996) and Zeidner (1998) who raise the need to adapt the coping strategy to the type of response mainly affected in each individual, and the possibility of not being successful using the same therapeutic procedures with all students who have test anxiety (Escolar \& Serrano, 2012).

Finally, we are aware that every piece or research is merely indicative and barely conclusive (frequently inconclusive). The findings in behavioral research must be replicated, although the repli- cation rarely is fully (if at all) accomplished (Yong, 2012). In this sense, the present research constitutes a replication of our past research, reasserting what we have previously found with different variables and analytical approaches. This replication is the basis of our confidence on the results presented in this paper. Anyway, we are aware that each result must be taken with caution.

\section{Acknowledgements}

The authors thank the Psychological Care Unit at the Faculty of Psychology at the University of Salamanca for starting test anxiety treatment groups and allow us to carry them out. Consequently, we would like to thank the ninety-four students that have been the sample for this research for the trust they have placed in our work as a way to alleviate their fears and anxieties.

\section{References}

Allen, G. J. (1980). The behavioral treatment of test anxiety: Therapeutic innovations and emerging conceptual challenges. In M. Herson, R. Eisler \& P. Miller (Eds.), Progress in behavior modification (pp. 81-123). New York: Academic Press.

Amutio, A., \& Smith, J. C. (2008). Stress and irrational beliefs in college students. Ansiedad y Estrés, 14, 211-220.

Beyth-Marom, R., Fidler, F., \& Cumming, G. (2008). Statistical cognition: Towards evidence-based practice in statistics and statistics education. Statistics Education Research Journal, 7, 20-39.

Bonaccio, S., Reeve, C.L., \& Winford, E.C. (2012). Text anxiety on cognitive ability test can result in differential predictive validity of academic performance. Personality and Individual Differences, 52, 497-502.

Can, P.B., Dereboy, C., \& Eskin, M. (2012). Comparison of the effectiveness of cognitive restructuring and systematic desensitization in reducing 
high-stakes test anxiety. Turkish Journal of Psychiatry, 23(1), 9-17.

Conley, K.M., \& Lehman, B.J. (2012). Test anxiety and cardiovascular responses to daily academic stressors. Stress and Health, 28, 41-50.

Cumming, G. (2007). Inference by eye: Pictures of confidence intervals and thinking about levels of confidence. Teaching Statistics, 29, 89-93.

Cumming, G. (2009). Inference by eye: Reading the overlap of independent confidence intervals. Statistics in Medicine, 28, 205-220.

Cumming, G. (2010). p values versus confidence intervals as warrants for conclusions that results will replicate. In B. Thompson \& R. Subotnik (Eds.), Research methodologies for conducting research on giftedness. Washington, DC: APA Books.

Cumming, G., Fidler, F., Leonard, M., Kalinowski, P., Christiansen, A., Kleinig, A., et al. (2007). Statistical reform in Psychology: Is anything changing? Psychological Science, 18, 230-232.

Cumming, G., \& Finch, S. (2005). Inference by eye: Confidence intervals, and how to read pictures of data. American Psychologist, 60, 170-180.

Cumming, G., \& Maillardet, R. (2006). Confidence intervals and replication: Where will the next mean fall? Psychological Methods, 11, 217-227.

Cunha, M., \& Paiva, M.J. (2012). Text Anxiety in Adolescents: The role of self-criticism and acceptance and mindfulness skills. The Spanish Journal of Psychology, 15(2), 533-543.

Delgado, J. (Junio 2007). "Inferencia a ojo" no es igual que "todo vale". ["Inferring by eye" is not the same as "anything goes"]. Ponencia presentada en la XI Conferencia Española e Iberoamericana de Biometría, Salamanca, España.

Ergene, T. (2003). Effective interventions on test anxiety reduction. School Psychology International, 24(3), 313-328.

Erwin-Grabner, T., Goodill, S. W., Hill, E. S., \& Neida, K. V. (1999). Effectiveness of dance/ movement therapy on reducing test anxiety.
American Journal of Dance Therapy, 21(1, Spring/Summer), 19-34.

Escalona, A., \& Miguel-Tobal, J. J. (1996). La ansiedad ante los exámenes: Evolución histórica y aportaciones prácticas para su tratamiento. [Test anxiety: Historical evolution and practical contributions for treatment] Ansiedad y Estrés, 2, 195-209.

Escolar, M. C. (2007). Eficacia diferencial de estrategias de afrontamiento de la ansiedad ante los exámenes universitarios en función de la variable principalmente afectada [Differential efficacy of anxiety coping strategies for university examinations depending on the primarily affected variable] (Unpublished doctoral dissertation). Universidad de Salamanca, España.

Escolar, M.C., \& Serrano, I. (Octubre 2012). Eficacia de las herramientas cognitivo-conductuales para disminuir la ansiedad en el ámbito educativo. [Effectiveness of cognitive-behavioral tools to reduce anxiety in the educational environment] Boletín de la SEAS, 37, 8-21.

Federer, W.T., \& King, F. (2007). Variations on Split Plot and Split Block Experiment Designs. New Jersey: John Wiley \& Sons.

Finger, R., \& Galassi, J.P. (1977). Effects of modifying cognitive versus emotionality responses in the treatment of test anxiety. Journal of Consulting and Clinical Psychology, 45, 280-287.

Fletcher, T. M., \& Spielberger, C. D. (1995). Comparison of cognitive therapy and rational-emotive therapy in the treatment of test anxiety. In C. D. Spielberger \& P. R. Vagg (Eds.), Test anxiety: Theory, assessment, and treatment (pp. 153169). Washington, DC: Taylor \& Francis.

Fox, J. (2008). Applied regression analysis, linear models, and related methods. Thousand Oaks. CA: Sage.

Furlan, L.A., Sanchez Rosas, J., Heredia, D., Piemontesi, S., \& Illbele, A. (2009). Estrategias de aprendizaje y ansiedad ante los exámenes en estudiantes universitarios. [Learning strategies 
and test anxiety in university students] Pensamiento Psicológico, 5(12), 117-124.

Gaudry, E., \& Spielberger, C. D. (1971). Anxiety and educational achievement. New York: Wiley.

Gonzalez, H. P. (1995). Systematic desensitization, study skills counselling, and anxiety-coping training in the treatment of test anxiety. In C. D. Spielberger \& P. R. Vagg (Eds.), Test anxiety: Theory, assessment, and treatment (pp. 117132). Washington, DC: Taylor \& Francis.

Gutiérrez-Calvo, M. (1996). Ansiedad y deterioro cognitivo: Incidencia en el rendimiento académico. [Anxiety and cognitive impairment: Impact on academic performance] Ansiedad y Estrés, 2, 173-194.

Hembree, R. (1988). Correlates, causes, and treatment of test anxiety. Review of Educational Research, 58, 47-77.

Hernández, J. M., Pozo, C., \& Polo, A. (1994). Ansiedad ante los exámenes: un programa para su afrontamiento de forma eficaz. [Test anxiety: A program for effectively coping]Valencia: Promolibro.

Holroyd, K.A. (1976). Cognition and desensitization in the group treatment of test anxiety. Journal of Consulting and Clinincal Psychology, 44, 991-1001.

Kaplan, R.M., Mccordick, S.M., \& Twitchell, M. (1979). Is the cognitive or the behavioral component which makes cognitive- behavior modification effective in test anxiety. Journal of Counseling Psychology, 26, 371-7.

Kirk, R. E. (1995). Experimental design: Procedures for the behavioral sciences. Monterey (CA): Brooks \& Cole.

Liebert, R. M., \& Morris, L. W. (1967). Cognitive and emotional components of test anxiety: A distinction and some initial date. Psychological Reports, 22, 175-178.

Loftus, G.R., \& Masson, M.E.J. (1994). Using Confidence intervals in within-subject designs. Psychonomic Bulletin \& Review, 1, 476-490.
Lowe, P.A., \& Ang, R.P. (2012). Cross-cultural examination of test anxiety amogn US and Singapore students on the Test Anxiety Scale for Elementary Students (TAS-E). Educational Psychology, 32(1, January), 107-126.

Martínez-Monteagudo, M.C., Inglés, C.J., Cano-Vindel, A., \& García-Fernández, J.M. (2012). Estado actual de la investigación sobre la teoría tridimensional de la ansiedad de Lang.[Current status of research on Lang's three-dimensional theory of anxiety] Ansiedad y Estrés, 18(2-3), 201-219.

McMillan, J.R., \& Osterhouse, R.A. (1972). Specific and generalized anxiety as determinants of outcome with desensitization of text anxiety. Journal of Counseling Psychology, 19, 518-521.

Meehl, P.E. (1997). The problem is epistemology, not statistics: Replace significance tests by confidence intervals and quantify accuracy of risky numerical predictions. In L.L. Harlow, S.A. Mulaik, \& J.H. Steiger (Eds.), What if there were no significance tests? (pp. 393-425). Mahwah, NJ: Erlbaum.

Miralles, F., \& Sanz, M.C. (2011). Cómo enfrentarse con éxito a exámenes y oposiciones. [How to successfully cope with examinations and competitions] Madrid: Pirámide.

Miralles, F., \& Hernández, I. (Marzo 2012). La ansiedad ante los exámenes. [Test anxiety] Boletín de la SEAS (36), 9-16.

Naveh-Benjamin, M. (1991). A comparison of training programs intended for different types of test-anxious students: Further support for an information-processing model. Journal of Educational Psychology, 83, 134-139.

Naveh-Benjamin, M., McKeachie, W. J., \& Lin, Y.-G. (1987). Two types of test-anxious students: Support for an information processing model. Journal of Educational Psychology, 79, 131-136.

Nemati, A., \& Habibi, P. (2012). The effect of practicing pranayama on test anxiety and test 
performance. Indian Journal of Sciencie and Technology, 5(4), 2645-2650.

Onwuegbuzie, A. J., \& Daley, C. E. (1996). The relative contributions of examination-taking coping strategies and study coping strategies to test anxiety: A concurrent analysis. Cognitive Therapy and Research, 20(3), 287-303.

Orejudo, S., Herero, M. L., Ramos, T., Turrado, F., \& Nuño, J. (2007). Evolución del miedo a hablar en público en estudiantes universitarios. Predictores de cambio a lo largo de un curso académico. [Evolution of fear of public speaking in university students. Predictors of change over an academic year] Ansiedad y Estrés, 13, 87-100.

Osterhouse, R. A. (1969). A comparison of desensitization and study-skills training for the treatment of two kinds of test-anxious students. Unpublished doctoral dissertation, Ohio State University.

Osterhouse, R. A. (1972). Desensitization and studyskills training as treatment for two types of test-anxious students. Journal of Counseling Psychology, 19, 301-307.

Parker, J. C. I., Vagg, P. R., \& Papsdorf, J. D. (1995). Systematic desensitization, cognitive coping, and biofeedback in the reduction of test anxiety. In C. D. Spielberger \& P. R. Vagg (Eds.), Test anxiety: Theory, assessment, and treatment (pp. 171-182). Washington, DC: Taylor \& Francis.

Paulman, R. G., \& Kennelly, K. J. (1984). Test anxiety and ineffective test taking: Different names, same construct? Journal of Educational Psychology, 76(2), 279-288.

Piemontesi, S., Heredia, D., Furlan, L., Sanchéz-Rosas, J., \& Martínez, M. (2012). Ansiedad ante los exámenes y estilos de afrontamiento ante el estrés académico en estudiantes universitarios. [Test anxiety and coping styles for academic stress in university students] Anales de Psicología, 28(1), 89-96.

Polo, A., Hernández, J. M., \& Pozo, C. (1996). Evaluación del estrés académico en estudiantes universitarios. [Evaluation of academic stress in university students] Ansiedad y Estrés, 2, 159-172.

Pozar, F.F. (1979). Inventario de hábitos de estudio: IHE. [Inventory of study habits: IHE] Madrid: TEA.

Putwain, D.W., \& Sysmes, W. (2012). Achievement goals as mediators of the relationship between competence beliefs nad test anxiety. British Journal of Educational Psychology, 82, 207224.

$\mathrm{R}$ Core Team (2013). R: A language and environment for statistical computing. R Foundation for Statistical Computing, Vienna, Austria. Retrieved from: http://www.R-project.org/

Rosenthal, R., Rosnow, R.L., \& Rubin, D.B. (2000). Contrasts and effect sizes in behavioral research: a correlational approach. Cambridge: Cambridge University Press.

Sapp, M. (1999). Test anxiety. Applied research, assessment, and treatment interventions. Lanham, Maryland: University Press of America.

Sarason, I.G. (1978). The Test Anxiety Scale: concept and research. In C.D. Spielberger \& I.G. Sarason (Eds.), Stress and anxiety (vol. 5, pp. 193-216). Washington DC: Hemisphere.

Sarason, I.G. (1984). Stress, anxiety, and cognitive interference: Reactions to test. Journal of Personality and Social Psychology, 46, 929-938.

Serrano, I., \& Delgado, J. (1990). Ansiedad ante los exámenes, ¿estado o rasgo?: Tratamiento conductual. [Test anxiety, state or trait? Behavioral Treatment.] Studia Paedagogica, 22, 81-93.

Serrano, I., \& Delgado, J. (1991). Estrategias de afrontamiento y ansiedad ante los exámenes. [Coping strategies and test anxiety] Revista de Psicología General y Aplicada, 44, 447-456.

Serrano, I., Delgado, J., \& Escolar, M. C. (2010). Eficacia diferencial de estrategias de afrontamiento en la reducción de la ansiedad ante los exámenes en función del tipo de variable principalmente afectada. [Differential efficacy of coping strategies in reducing test anxiety depending on 
the primarily affected variable type]. Ansiedad y Estrés, 16 (2-3), 109-126.

Serrano, I. \& Escolar, M. C. (2011). Psicopatología de la ansiedad ante los exámenes: dimensiones y componentes. [Psychopathology of test anxiety: dimensions and components]. Escuela y Psicopatología, 2, 135-168.

Serrano, I., Escolar, C., \& Delgado, J. (2002). Eficacia diferencial de estrategias de afrontamiento en la reducción de la ansiedad ante los exámenes [Differential efficacy of coping strategies in reducing test anxiety]. Análisis y Modificación de Conducta, 28, 523-550.

Serrano, I., Escolar, M. C., \& Delgado, J. (2011). Eficacia de tres estrategias de afrontamientos en la reducción de la ansiedad ante los exámenes en función del tipo de variable principalmente afectada. [Efficacy of three confrontation strategies in reducing test anxiety depending on the primarily affected variable type] In J.M. Román, M.A. Carbonero \& J.D. Valdivieso (Comps.), Educación, aprendizaje y desarrollo en una sociedad multicultural (pp. 1115-1133). Madrid: Ediciones de la Asociación Nacional de Psicología y Educación.

Sharma, S. (2002). Anxiety in students. Psychological Studies, 47(1-3), 49-53.

Spielberger, C.D. (1972a). Anxiety as an emotional state. In C.D. Spielberger (Ed.), Anxiety: $\mathrm{Cu}$ rrent trends in theory and research (vol. 1). New York: Academic Press.

Spielberger, C.D. (1972b). Conceptual and methodological issues in anxiety research. In C. D. Spielberger (Ed.), Anxiety: Current trends in theory and research (Vol. 2). New York: Academic Press.

Spielberger, C.D. (1980). Test anxiety inventory. Palo Alto, CA: Consulting Psychologists Press.

Spielberger, C. D., Anton, W. D., \& Bedell, J. R. (1976). The nature and treatment of test anxiety. In M. Zuckerman \& C.D. Spielberger (Eds.), Emotions and anxiety: New concepts, methods and applications (pp. 317-344). New York: LEA/Wiley.

Spielberger, C.D., Gonzalez, H.P., \& Fletcher, T. (1979). Test anxiety reduction, learning strategies, and academic performance. In H. F. J. O'Neil \& C. D. Spielberger (Eds.), Cognitive and affective learning strategies (pp. 111-131). New York: Academic Press.

Spielberger, C.D., Gonzalez, H. P., Taylor, C. J., A1gaze, B., \& Anton, W. D. (1978). Examination stress and test anxiety. In C.D. Spielberger \& I.G. Sarason (Eds.), Stress and anxiety (Vol. 5, pp. 167-191). Washington: Hemisphere Publishing Corporation.

Spielberger, C.D., Gorsuch, R.L., \& Lushene, R.D. (1970). Manual for the State-Trait Anxiety Inventory. Palo Alto, CA: Consulting Psychologists Press.

Spielberger, C.D., \& Vagg, P. R. (1995). Test anxiety: A transactional process model. In C. D. Spielberger \& P.R. Vagg (Eds.), Test anxiety: Theory, assessment and treatment (pp. 3-14). Washington, DC: Taylor \& Francis.

Szafranski, D.D., Barrera, T.L., \& Norton, P.J. (2012). Test anxiety inventory: 30 years later. Anxiety, Stress, \& Coping: An International Journal, 25(6), 667-677.

Vagg, P. R., \& Spielberger, C. D. (1995). Treatment of test anxiety: Application of the transactional process model. In C.D. Spielberger \& P.R. Vagg (Eds.), Test anxiety: Theory, assessment, and treatment (pp. 197-215). Washington, DC: Taylor \& Francis.

Valero, L. (1999). Evaluación de ansiedad ante exámenes: datos de aplicación y fiabilidad de un cuestionario CAEX. [Evaluation of test anxiety: Application data and reliability of the CAEX questionnaire]. Anales de Psicología, 15, 223231.

Wagaman, G. L.; Cornier, W. H. \& Cornier, L. S. (1975). Cognitive modification on test-anxious students. Paper presented at the meeting of the 
American Educational Research Association, Washington, DC.

Wolpe, J. (1958). Psychotherapy by reciprocal inhibition. Stanford, CA: Stanford University Press.

Yong, E, (2012). Replication studies: Bad copy. $\mathrm{Na}$ ture, 298-300

Reception date: January 31, 2014

ficceptance date: February 23, 2015
Zeidner, M. (1998). Test anxiety: The state of the art. New York: Plenum Press.

Zeidner, M. (2007). Test anxiety in educational contexts: Concepts, findings, and future directions. In P. A. Schutz \& R. Pekrun (Eds.), Emotion in education (pp. 165-184). Boston: Elsevier Academic Press. 